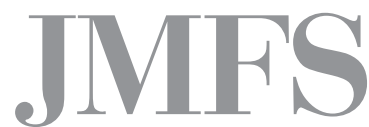

Journal of Management and Financial Sciences
Volume X

Issue 30 (December 2017)

pp. 27-41

Warsaw School of Economics

Collegium of Management and Finance

Katarzyna Górak-Sosnowska

Collegium of Management and Finance

Warsaw School of Economics

Michał Matusewicz

Collegium of Management and Finance

Warsaw School of Economics

Irena Senator

Collegium of Management and Finance

Warsaw School of Economics

\title{
Managing Students' Affairs at Higher Education Institutions: A Qualitative Analysis of Selected Tasks and Processes ${ }^{1}$
}

ABSTRACT

Management of students' affairs is a significant process supporting teaching at every higher education institution. Units responsible for this administrative task (mostly referred to as dean's offices) not only monitor, verify, and document the educational process of each student, but also regulate some crucial aspects of formal teacher-student relations. While all dean's offices serve the same purpose - i.e. provide administrative support to the teaching process - and work within a similar legal framework, they manage students' affairs in different ways. The aim of the article is to explore and analyse these differences. Basing

1 This research was supported by a research grant of the Rector of Warsaw School of Economics, Efektywność funkcjonowania dziekanatów na polskich uczelniach, RG/EFD/17. 
on 26 individual in-depth interviews and visits to dean's offices in Polish HEIs the paper analyses the organisation of work and selected core processes which are conducted at these units: processing students' applications, removing from students' lists, organising thesis defences, and organising examination schedules.

Keywords: higher education, dean's office, students' affairs, management JEL Code: I230

\section{Introduction}

Management of students' affairs at the administrative level is a process often underestimated in and by higher education institutions (HEIs). Their main aim is to educate their students, i.e. provide them with knowledge, abilities and social skills. Thus, the most important issue is the content and quality of the educational process. Managing this process at the administrative level is definitely of a less rudimental nature, but still significant since it actually enables carrying out the educational process by verifying, monitoring and documenting the progress of each student. Moreover, the quality of students' affairs management is one of the two most important components of how the overall quality of education is perceived with some researchers claiming that it is almost as important as the quality of teaching. It is because the unit responsible for managing students' affairs serves as an intermediary between the students and the academics at HEIs ${ }^{2}$.

The unit which is responsible for administration of students' affairs related to their education at HEIs is the dean's office. While there has been a lot of research focused on quality of education, dean's offices as units responsible for the administrative burden of education (and thus also for its quality) remained beyond the scope of scientific interest ${ }^{3}$. This article hopes to fill in this gap by exploring and analysing key processes of how students' affairs are managed at Polish HEIs. The research is

2 P. Sultan, H.Y. Wong, Antecedents and consequences of service quality in a higher education context. A qualitative research approach, "Quality Assurance in Education", 2013 vol. 21, no. 1, p. 77.

3 The very few exceptions from this rule are: A. Klaus, R. Ryńca, M. Kowalski, Analiza kosztów dziekanatu w szkole wyższej z wykorzystaniem rachunku kosztów działań, "Badania operacyjne i decyzje", no. 1, 2007; A. Nowakowska-Krystman, Sprawność organizacyjna uczelni w oczach studentów: analiza jakości obsługi administracyjnej studentów, "Zeszyty Naukowe” 2011, no. 167, Uniwersytet Ekonomiczny w Poznaniu; Zarządzanie kadrami uczelni: Jakość w zarządzaniu uczelnią, K. Czekaj-Kotynia (Ed.), Instytut Nauk Społeczno-Ekonomicznych, Łódź 2013; Efektywne zarządzanie kadrami na uczelni, P. Błędowski (Ed.), Instytut Nauk Społeczno-Ekonomicznych, Łódź 2013. 
based on 29 individual in-depth interviews conducted by the authors with the heads of dean's offices in selected Polish HEIs (see the attached list at the end of the article) in summer 2017. In order not to reveal specific procedures of dean's offices, we have decided to code them basing on the following rules: non-public HEIs are coded with $\mathrm{N}$, while public HEIs are split between universities (coded with $\mathrm{U}$ ) and economic universities (coded with E).

The aim of the article is to explore and analyse differences between dean's offices functioning in Polish universities. Basing on 29 individual in-depth interviews and visits to dean's offices in Polish HEIs, the paper analyses the organisation of work and selected core processes which are conducted at these units: processing students' applications, removing from students' lists, organising thesis defences, and organising examination schedules.

Our basic assumption which enabled us to analyse and compare selected processes at different dean's offices is that they share a lot in common: all of them provide administrative support of the educational process at HEIs and all work within a certain national legal framework. At the same time their work organisation and internal procedures differ between and even within HEIs. For further analysis we have selected these processes and procedures which fulfil three following criteria:

- They have been identified in the majority of dean's offices (i.e. they are universal);

- They are carried out solely or mostly by the dean's office itself (i.e. not in collaboration with other administrative units);

- They are complex (i.e. not single tasks like e.g. distribution of student IDs).

\section{Dean's Office in HEl's Structure}

There are three different models of placing dean's offices in HEIs' structure, which we have identified in the faculties that we visited:

- Faculty model - students' affairs are managed by a dean's office, i.e. in charge of all administrative affairs at the faculty. This model has been identified e.g. at $\mathrm{E}_{2}$, in which the dean's office is responsible for managing affairs of the deans, a wide range of students' and graduate services, managing post graduate studies, the support of academic staff, didactics, and the administration of institutes and departments, as they have no own secretaries. The complexity and scope of activities carried out by dean's office $\mathrm{E}_{2}$ explains why students' affairs are managed just by half of its staff.

- Dean's office model - the basic task of the dean's office is to manage students' affairs. This model has been identified e.g. at $\mathrm{N}_{3}$ or $\mathrm{N}_{4}$. The scope of their tasks 
differs depending on HEI, e.g. dean's office $\mathrm{U}_{8}$ is also responsible for the quality of education, course schedules and other issues related to didactics, while $\mathrm{N}_{3}$ is not. In this case all dean's office's staff except for the head of the unit manage students' affairs.

- Mixed model - students' affairs are managed partly at the dean's office, and partly at the departments and institutes responsible for BA and MA studies. This way the dean's office of $U_{6}$ is organised: the dean's office is responsible for general affairs for all the students at the faculty, such as scholarships, or international exchanges, while other issues related to the course of studies are managed at faculty departments or institutes. Around half of the staff at these units is responsible for managing students' affairs, while at the dean's office it is less than a half.

The first two models are centralised, and so all the processes are carried out for the whole faculty. The mixed model is partly decentralised with some processes conducted at the central level, while some others at departments and institutes.

\section{Size of the Dean's Office}

The dean's offices in our sample differ not only in their structure, but also in size. The smallest one manages affairs of less than 2 thousand students, while the biggest - of almost 8 thousand. All but one dean's offices run studies at both bachelor's and master's levels, with - in most cases - bachelor's students comprising the majority of students. The number of staff varies from 4 to 21 , while the number of employees managing students' affairs varies from 3 to 13 . Having the number of students and of staff one can calculate the average number of students per employee (keeping in mind that the scope of service differs between the dean's offices). This average number can be calculated in two ways:

- depending on the time of studies - sometimes students might be divided between the employees according to whether they study full-time or part-time (i.e. at weekends);

- without any relation to the time of studies - then the employees manage affairs of the students who study the same major.

In the first case the average number of students per employee ranges from 202 (at $\mathrm{N}_{4}$ ) to 605 (at $\mathrm{U}_{8}$ ), with the average of 400 in case of full-time studies. In the case of part-time studies, it is from $61\left(\right.$ at $\left.\mathrm{E}_{9}\right)$ to $512\left(\right.$ at $\left.\mathrm{U}_{2}\right)$ with the average of 300 . In all the offices but two the average number of part-time students per employee is 100-300 lower comparing to full-time students. The difference results from the fact that part-time students pay tuition fees and this also has to be managed by the dean's 
office employees. Thus, the employees who manage part-time students' affairs have more responsibilities comparing to those who work with full-time students. In the second case (i.e. without dividing students between full-time and part-time ones) the average number of students per employee varies from 326 (at $\mathrm{E}_{6}$ ) to 700 (at $\mathrm{N}_{5}$ ).

\section{Working Hours}

In terms of working hours, dean's offices are just as any other office, as the work starts at 7:30-8:00 and lasts till 15:30-16:00. Many offices have, moreover, afternoon office hours, and all but one - an extra working day on Saturdays for part-time students (a few of them are also open on Sundays, both public e.g. $\mathrm{E}_{12}$ and non-public ones, e.g. $\mathrm{N}_{2}$ ).

The offices are open for students 3-4 hours daily on average. In many cases the dean's offices are closed for students for one working day; this is a day dedicated for internal office work, very much appreciated by the staff. This makes around 14-16 office hours a week (e.g. at $\mathrm{E}_{10}$ or $\mathrm{E}_{4}$ ). In some of them, office hours for students are much longer, almost as long as the working hours. Dean's office $\mathrm{N}_{4}$ is open 5 hours a day for 4 days and 7 hours at working weekends. Dean's office $\mathrm{E}_{6}$ is open even longer - 7 days a week, while students are served 6 hours every day (which makes 42 hours a week). The $\mathrm{N}_{2}$ dean's office is open 8 hours a day, 7 days a week, which makes in total 56 hours weekly and is the longest possible time.

\section{Overview of the Processes}

As indicated by different models of placing dean's offices within the HEI structure, some of them are engaged into much more administrative work than just managing students' affairs. In our research we have focused, however, only on administrative work related to students' affairs. Some processes are common for all the offices, such as proceeding students' applications, or preparing and issuing diplomas and supplements. All but one dean's office organise thesis defences and all but two notify students about a possible removal from the list of students. Most of the dean's offices deal with a number of students' affairs including: monitoring students' payments, internships, scholarships, foreign exchanges, and faculties' website. Some offices organise schedules of examination sessions and confirm teaching hours for academics. Hardly any dean's office prepares schedules of classes, accepts students' payments, issues invoices or is responsible for recruitment. 
In the following parts of the article we are going to analyse selected processes of students' affairs management. We have decided to choose these processes for four reasons. Firstly, these processes are conducted in the majority or all of the offices. Secondly, they illustrate how work is organised. Thirdly, these processes are to a great extend universal for every student - there is a huge change, or almost certainty, that each student will get through them. Lastly, these processes are complex and combined of more than a single task. This way it is possible to see how work at a dean's office is organised.

\section{Organisation of Work}

While all dean's offices manage students' affairs, the work is organised in different ways. Two main differences refer to: (1) ascribing (or not) students to particular student assistants at the dean's office and (2) organising work in accordance with the premises of the dean's office. In most dean's offices, students' affairs are managed by dedicated student assistants, i.e. the dean's office employees get documents of concrete students and manage their affairs from the day of recruitment to their graduation and sending their files to the HEI's archives. There are two ways of ascribing students to the employees:

- according to specialization - the employee manages affairs of students of a certain major, or year. This way the employee is specialized in this particular type or field of studies: e.g. at dean's office $\mathrm{U}_{3}$ every employee is responsible for a particular year of studies, while at dean's office $\mathrm{U}_{8}$ students are distributed between the employees according to the majors they study.

- According to the number of students - the employees manage affairs of a more or less similar number of students, regardless of their year or major. This way the employees are all-embracing and can substitute each other easily. This is the way that work is organised at dean's office $\mathrm{E}_{4}$ due to the fact that no other distribution of students among the employees was possible.

At one dean's office, $\mathrm{N}_{2}$, students are not ascribed to any particular student assistant, i.e. all the assistants care for all the students. All work is distributed between the employees by the head of the dean's office. This way all the employees can perfectly substitute and replace each other, as student files are not ascribed to a particular employee, but to the dean's office as a whole. However, it should be added that the faculty is very small with less than 2 thousand students and 6 employees so this type of work organisation could be possible. 
When it comes to the premises, in the vast majority of the offices employees work in several rooms, located in proximity or separated only by an internal door. We have encountered two exceptions from this rule. At faculty $\mathrm{N}_{3}$, the dean's office premises are located on far sides of the hallway, which makes their management difficult, as the employees are located in different spots of the floor. Faculty $U_{9}$ has actually three separate dean's offices (one for every major) with a room of a respective dean attached to the dean's office. The head of them works in a separate room.

There are usually from 2 to 4 employees in one room. During office hours students enter the room and are served at their desks or at a counter. Other students wait for their turn in front of the door. It seems that premises linked with each other by an internal door are most functional - this way the employees can easily and quickly communicate with each other, while being located in separate rooms, rather than open space, gives them silence they need for their work. At the same time, it seems that being located in a separate room makes it hard for the employees to guess if the dean is around, unless (s)he comes to their room. That is why some deans have weekly office hours dedicated to their employees. Moreover, several dean's offices introduced queue machines. Not only have these machines made the lives of the students easier, as they do not have to literally stand in a queue, but also of the dean's office employees, as they know how many students they are going to serve, and they can distribute the work between themselves in a more efficient way.

\section{Processing Students' Applications}

It would probably be an exaggeration to say that every student submits at least one application to the dean. Yet the applications are a formal channel of communication between students and the university. Through applications students apply for different things which are significant in the course of their studies, especially when it deviates from the original plan or programme (e.g. a conditional approval for the next semester, semester re-take, renewal of studies etc.). The applications are (1) submitted by students to the dean's office, then (2) the decision is taken by the dean, and (3) communicated to the student by the respective student assistant. In this framework all the offices carry this process in the same manner - just as in the case of any other office or institution. The differences lay in the details of every of these steps.

In the case of submission of applications (1) a student usually submits it to his/ her assistant at the dean's office. At some faculties $\left(\mathrm{U}_{9}, \mathrm{E}_{4}, \mathrm{~N}_{1}\right.$ and $\left.\mathrm{N}_{5}\right)$ a student can leave his/her application in a mailbox attached to the dean's office's door, and so 
(s)he does not have to queue. Applications are submitted in a written form, however, under some circumstances it is allowed to send the application scanned via e-mail (e.g. in $\mathrm{N}_{3}$ or $\mathrm{U}_{4}$ ). Some of HEIs, e.g. faculties $\mathrm{N}_{4}, \mathrm{U}_{7}$ or $\mathrm{U}_{5}$ introduced a system for submission of applications online. The whole process of proceeding the application is also online - the dean takes his/her decision online, it is also transmitted online to the student. The decision is then printed and put into the student's files.

Almost all the faculties introduced standardised application forms available on their websites. These forms fulfil two basic roles: they facilitate students in writing the application, and enable dean's office employees easier control whether the form is complete and appropriate. Most offices introduced separate forms for different types of cases. Usually a form has a space for personal data, the addressee, and a template to fill in the request and its substantiation, and a space for a signature at the bottom. The most detailed form was prepared at $\mathrm{U}_{8}$ as the form is divided into layers - a student's data and request are at the top, below there is a space for remarks of the dean's office staff, later a space for the dean, and at the very bottom the student has to sign that (s)he acknowledged the decision. On the contrary, dean's office $\mathrm{N}_{1}$ has just one universal form of application. There are all possible reasons for submitting the application listed and a student only needs to select the proper one and submit a substantiation, if needed. The student submits the application online, and gets the dean's answer through extranet.

In some HEIs the applications are registered - either online as students submit them online, or in a paper registry. However, in many other HEIs the applications are not registered, only settled and put to student files. The most comprehensive but also demanding procedure is at faculty $\mathrm{E}_{6}$ where every single application has to be registered with a number and recorded in a dedicated system. Some faculties, including $\mathrm{N}_{1}$ and $\mathrm{N}_{3}$, developed a unique type of work division, with the office being divided between the front office and back office. The employees who sit at the front office collect the applications and transfer them to the back office, i.e. to the employees who register and process them. All the employees work interchangeably in the front and back office. This type of work division translates into higher efficiency - those who sit at the front office focus on student service, while those at the back office can work in silence. Moreover, this type of work division makes it possible to extend office hours, even though no employee works more than 4 hours a day at the front office.

Examination of applications (2) is proceeded at different levels of formality. Sometimes an essential condition is a written annotation of the respective student assistant (e.g. at $\mathrm{U}_{8}$ ). More often an annotation is only necessary if there are inconsistencies in the application, or a student's case is complicated. In other cases, the application is simply passed on to the dean. At some offices the employees do not write any 
annotations on students' applications, only discuss all cases with the dean personally (e.g. at dean's office $\mathrm{U}_{6}$ ). Dean's office $\mathrm{N}_{2}$ has even more liberty as the head of the dean's office sets with the dean the rules of conduct, and so the employees can communicate to the students how the application is going to be settled (if only the case is a standard one). Individual hard cases are settled during the dean's office hours.

The decision (3) is communicated to the students in two different ways: proactive or reactive. In the first case the student receives the decision just after it has been taken, as soon as it is entered into the system (e.g. extranet or Virtual Dean's office). In the second case the student has to learn about the decision by himself/herself. $\mathrm{He} /$ she can do it by phone, e-mail or personally. Students of faculties $\mathrm{U}_{8}$ or $\mathrm{E}_{1}$ need to sign that they have acknowledged the dean's decision.

\section{Schedules of Examination Sessions}

Setting the time of examination sessions within the academic year does not depend on the dean's office, even if it determines its work organisation: it is after the end of the examination session and time for its prolongation, when the dean's office can proceed with semester decisions for all the students, and - if needed - allow them to conditionally enrol in the next semester or to retake a semester; if that is not possible, then it should remove them from the students' list. Moreover, in the case of students who finish their classes, the dean's office has to check all their courses and prepare their files for their thesis defence.

In most of the dean's offices that we have visited, there are two examination sessions, and an additional time to prolong the session in motivated or documented cases. The first session starts around May/June, and the second in September (even though we have found one HEI which conducts the second session in July). If the second session is organised at the latest till the first half of September, it is possible to conclude all semester procedures before the start of the new academic year. Having the second session in early July (just like at faculty $\mathrm{E}_{12}$ ) makes the things even smoother for all the parties - students, teachers, and the dean's office. Students can still remember what they have learned in their courses, and can go for holidays knowing if they have passed all the exams or not. The teachers have to stay at the university anyway, since they have to participate in bachelor's students' thesis defences. The dean's office can use the loose time to proceed all the paperwork and conclude the semesters of all the students. At some faculties, e.g. $\mathrm{E}_{6}$, there is an extra earlier session for students who are about to graduate, so that they can focus on finishing their theses on time. 


\section{Removal from the List of Students}

Removal from students' lists is an administrative decision which has certain rules to be fulfilled. The differences between the dean's offices lay, therefore, not in the merit, but in the way it is communicated and issued.

Almost all HEIs send notification about a possible removal from the list of students, which gives the students some time to react and respond. This time extends the whole procedure, as the notification has to be delivered by registered mail with a pick-up confirmation, and only after the notification is delivered one can start counting the time provided for students' response. Only then, after two weeks, the student can be removed from the list. The procedure of removing students from the list consists of several phases:

- Some dean's offices (e.g. $E_{7}$ ) start by selecting the students who might be removed from the list of students and they try to get in touch with them. This way they can protect the students who forgot something from the procedure by pressing them to take action. On the extranet of dean's office $\mathrm{N}_{2}$ there are alerts which remind students to follow all regulations related to the course of their studies on time. This way students are notoriously reminded, in case they miss something to complete the semester.

- The next step is the actual start of the procedure of removing a student from the list by sending a notification. One dean's office $\left(\mathrm{E}_{1}\right)$ sends written notifications in all possible cases, even in the case of re-taking a semester, or a conditional approval for the next semester. However, the vast majority sends these notifications only in the case of a possible removal from the students' list. If the removal is to occur due to financial reasons, it is often the financial unit which provides the dean's office with the list of students to be removed, or even sends the notifications on its own (this is the case of both public e.g. at $\mathrm{E}_{4}$, or $\mathrm{E}_{10}$ and non-public HEIs, e.g. $\mathrm{N}_{2}$ or $\mathrm{N}_{3}$ ).

- The last phase is the actual removal from the list of students.

Written notification about a possible removal from students' lists is burdensome for dean's office employees. Some faculties work on the possibility of sending these notifications via their internal Internet system. There is also one dean's office $\left(U_{6}\right)$ which does not always send notifications - if a student cannot do anything to avoid being removed, then the notification is not sent, as it would be useless anyway.

Decisions of removal from students' lists are not prepared at once, but rather depending on the reason for the removal. For instance, dean's office $\mathrm{E}_{2}$ starts with removing the students who did not take part in the examination session, then those 
who failed to obtain the proper number of ECTS, and finally it removes the students who did not start their studies. The dean's office removes also the students for lacking payments and monitors the payments twice per semester. All the students have to be removed within a time frame set by the end of the examination session on one end, and by the reporting system of POL-on on the other end.

\section{Organisation of Thesis Defences}

The thesis defence is the last constituent of the process of studying and the ultimate condition to graduate. Organisation of thesis defences, preparation of diplomas and supplements belong to the responsibilities of dean's offices. At some of them it is conducted by a separate unit (e.g. at $\mathrm{E}_{4}$ ) while in others every employee prepares diplomas and supplements for his/her own students (e.g. at $\mathrm{E}_{10}$ ).

Many offices organise two periods of theses defences - in June/July and in September (e.g. at $\mathrm{E}_{10}$ ). Others organise just one period for theses defences, and if the student fails to submit the thesis on time (s)he is removed from the list of students (e.g. at $\mathrm{U}_{3}$ ). The time of the defence is set in different ways - either the student is obliged to submit the thesis in a certain period of time before the defence takes place (e.g. 4 weeks ahead as at $\mathrm{N}_{2}, 2$ weeks ahead as at $\mathrm{E}_{10}$, or even 1 week ahead as at $\mathrm{E}_{12}$ ), or the dean's office is obliged to organise the defence within 3 months after the thesis has been submitted (e.g. at $\mathrm{E}_{2}$ ).

The ways of setting the time of the defence vary between the dean's offices. At dean's office $\mathrm{E}_{11}$ supervisors set the time at the dean's office in a calendar in which available dates are marked. It is a small faculty with around 2 thousand students, which means around 700 defences yearly, provided that all students submit their thesis on time. The small number of defences is indicated by the fact that they are headed by the dean or vice-deans. Faculty $\mathrm{E}_{12}$ is twice as big as $\mathrm{E}_{11}$. The supervisors reserve a day for the defences of their students and basing on this the schedule is prepared. The time of the defence is set at $\mathrm{E}_{3}$ when the student or the supervisor come to the dean's office and ask for a specific date. An interesting way of setting the time of thesis defences has been developed at dean's office $U_{7}$ - the supervisor organises the whole defence, i.e. sets the time and date with the reviewer, the student and the head of the commission. This date is communicated later to the dean's office, which prepares all the relevant documents. Sometimes thesis defences are organised by the secretaries from the department or institute where the supervisor works. This also seems to be an efficient way, as the secretaries have better access to the supervisors and can set with them a date that suits all the defence 
participants. It is also better for the supervisors to set the day with the secretary, rather than go to the dean's office.

As many of our interlocutors indicated, the thesis defence is rather a symbolic end of studies than a real exam, which eventually proves if a student shall graduate or not. For instance, at faculty $\mathrm{E}_{10}$ the defence lasts 15 minutes and consists only of questions related to the field of study (from a list of questions, or according to the supervisor's preferences). At $\mathrm{U}_{3}$ the defence lasts 30 minutes and there are two questions - from the major and from the thesis. Also in this case it is hardly imaginable that the student fails to pass. At $\mathrm{U}_{6}$ the defence lasts 20 minutes and comprises 2 questions from the thesis and one of 10 questions related to the field of studies available on the faculty's website.

It is worth stressing that students deliver their theses relatively fast, not only in the case of bachelor's studies, but also at the master's level. According to the head of dean's office $\mathrm{E}_{2}$ around $75 \%$ of students have their defence in June/July; at $\mathrm{E}_{3}$ it is around half of the students. However, at $\mathrm{U}_{6}$ most students defend their theses in September/October.

At two HEIs there is an additional level of quality control between the defence and issuing the diploma. At faculty $\mathrm{E}_{9}$ there is an extra control of student files, including the data on the diploma and the supplement before they are signed by the Rector and the dean. It is a formal control of the whole educational cycle and all necessary documents. At dean's office $\mathrm{N}_{2}$ each thesis is controlled by a commission after being submitted, approved by the supervisor and checked by the reviewer.

The virtual system of reviewing and submitting theses is a tool that smoothens the whole process. The thesis is uploaded to the system and sent to the supervisor, who checks and approves it, and later to the reviewer. The review is prepared and sent online. A printed copy of the thesis and review are available at the defence and then signed by the supervisor and the reviewer. This procedure has been implemented at dean's office $\mathrm{U}_{6}$ and has made the whole process much more effective. A similar procedure is conducted at $\mathrm{U}_{8}$ - the topic of the thesis is accepted by the board of the faculty and entered into the system by a dean's office employee. The thesis is uploaded by the student. Then it is transferred to the supervisor and the reviewer; the first one checks it and forwards for a plagiary check, while the latter writes a review. The student submits a printed thesis at the dean's office before the date of the defence.

Diplomas and supplements after the defence are prepared by students' assistants, or by a dedicated unit. In case of bigger faculties, the number of diplomas to prepare and issue is huge, so other employees help them with the workload. The supplements are printed at the dean's office, while diplomas ordered and printed outside of the dean's office, basing on the data submitted by the dean's office. 


\section{Conclusion}

All the tasks and processes are carried out at the dean's offices in different ways. Their work organisation results from internal regulations of HEIs and physical working conditions (e.g. available premises). HEIs' authorities define the scope of work of the offices and to some extent define when these tasks are to be fulfilled. Recruitment limits set the number of students to be enrolled. HEIs' infrastructure, premises, hardware and software define the way of work and the ability to carry out the tasks more or less effectively.

It is worth mentioning that some of the dean's offices came up with ways and solutions to organise their work better and more efficiently. Some of these tools and methods could be implemented in other offices, but often it is not possible for reasons that lay beyond the dean's office itself. In most cases it is an insufficient software, or HEIs' procedures which make some of these solutions hard to implement.

\section{Bibliography}

1. Efektywne zarzadzanie kadrami na uczelni, P. Błędowski (Ed.), Instytut Nauk Spoleczno-Ekonomicznych, Łódź 2013.

2. Klaus A., Ryńca R., Kowalski M., Analiza kosztów dziekanatu w szkole wyższej z wykorzystaniem rachunku kosztów działań, "Badania operacyjne i decyzje" 2007, no. 1.

3. Nowakowska-Krystman A., Sprawność organizacyjna uczelni w oczach studentów: analiza jakości obsługi administracyjnej studentów, "Zeszyty Naukowe” 2011, no. 167, Uniwersytet Ekonomiczny w Poznaniu.

4. Sultan P., Wong H.Y., Antecedents and consequences of service quality in a higher education context. A qualitative research approach, "Quality Assurance in Education" 2013, vol. 21 no. 1 .

5. Zarzadzanie kadrami uczelni: Jakość w zarządzaniu uczelnia, K. Czekaj-Kotynia (Ed.), Instytut Nauk Społeczno-Ekonomicznych, Łódź 2013.

\section{List of visited dean's offices}

1. Academy of Physical Education, Faculty of Tourism and Recreation (Warsaw, $13^{\text {th }}$ July 2017);

2. Academy of Special Education (Warsaw, $1^{\text {st }}$ August 2017);

3. Adam Mickiewicz University in Poznań, Faculty of English (Poznań, $21^{\text {st }}$ July 2017); 
4. Cracow University of Economics, Faculty of Commodity Science (Kraków, $12^{\text {th }}$ July 2017);

5. Cracow University of Economics, Faculty of Economics and International Relations (Kraków, 12 ${ }^{\text {th }}$ July 2017);

6. Cracow University of Economics, Faculty of Finance and Law (Kraków, 12 $2^{\text {th }}$ July 2017);

7. Cracow University of Economics, Faculty of Management (Kraków, $12^{\text {th }}$ July 2017);

8. Cracow University of Economics, Faculty of Public Economy and Administration (Kraków, 12 $2^{\text {th }}$ July 2017);

9. Jagiellonian University, Faculty of Philology, Institute of English Studies (Kraków, $12^{\text {th }}$ July 2017);

10. Jagiellonian University, Faculty of Philology, Institute of Management and Social Communication (Kraków, 12 $2^{\text {th }}$ July 2017);

11. Jagiellonian University, Faculty of Philology, Institute of Romance Studies (Kraków, $12^{\text {th }}$ July 2017);

12. Poznań University of Economics and Business, Faculty of Economics (Poznań, $21^{\text {st }}$ July 2017);

13. Poznań University of Economics and Business, Faculty of Management (Poznań, $21^{\text {st }}$ July 2017);

14. SWPS University of Social Sciences and Humanities (Wrocław, $10^{\text {th }}$ July 2017);

15. SWPS University of Social Sciences and Humanities (Warsaw, $10^{\text {th }}$ August 2017);

16. University of Economics in Katowice, Faculty of Economics (Katowice, $11^{\text {th }}$ July 2017);

17. University of Economics in Katowice, Faculty of Finance and Insurance (Katowice, $11^{\text {th }}$ July 2017);

18. University of Economics in Katowice, Faculty of Management (Katowice, $11^{\text {th }}$ July 2017);

19. University of Lodz, Faculty of Economics and Sociology (Łódź, 27 $7^{\text {th }}$ July 2017);

20. University of Lodz, Faculty of Management (Łódź, $7^{\text {th }}$ July 2017);

21. University of Silesia in Katowice, Faculty of Law and Administration (Katowice, $11^{\text {th }}$ July 2017);

22. University of Social Sciences, Faculty of Management (Łódź, $12^{\text {th }}$ June 2017);

23. University of Warsaw, Faculty of Economic Sciences (Warszawa, 21 ${ }^{\text {st }}$ June 2017);

24. University of Warsaw, Faculty of Geography and Regional Studies (Warszawa, $26^{\text {th }}$ July 2017);

25. Wrocław University of Economics, Faculty of Economic Sciences (Wrocław, $10^{\text {th }}$ July 2017); 
26. Wrocław University of Economics, Faculty of Engineering and Economics (Wrocław, $10^{\text {th }}$ July 2017);

27. WSB University (Chorzów, $11^{\text {th }}$ July 2017);

28. WSB University (Poznań, $21^{\text {st }}$ July 2017);

29. WSB University (Wrocław, $10^{\text {th }}$ July 2017). 
